\section{Flint Implements of the Bronze Age}

WHAT would appear to be a remarkable collection of flint implements of Bronze Age date, unusually numerous for the period, is reported (The Times, June 28) to have been found on Lightlands Farm, belonging to Mr. George Lawrence, of Frant, Sussex. It includes arrow-heads, tanged and barbed, scrapers, knives and flakes. Apparently the implements belong to a pygmy flint industry. The site is half a mile north-east of the camp of Saxonbury. It is on clay soil which has been ploughed for orchards. The flints in consequence have been widely scattered. It is pointed out that such sites are not common in the mid-Weald, to which the raw flint had to be carried either sixteen miles from the North Downs or eighteen miles from the South Downs. Pygmy implements are more commonly found on the sandy sites fringing the Weald.

\section{The Attempt on Mount Everest}

ONCE more the attempt to reach the summit of Mount Everest has failed. The Times announces that Captain Oliver, a member of the expedition, has returned to Kalimpong and that the other members may shortly be expected there. This year's party was a small one, but included men of great experience. Mr. H. W. Tilman, the leader, Mr. N. E. Odell, Captain P. R. Oliver, Mr. E. E. Shipton, Mr. F. S. Smythe and Dr. C. B. Warren had all had experience on Mount Everest and elsewhere, and Mr. P. Lloyd had distinguished himself on Nanda Devi. A message from Mr. Tilman to The Times confirms the news that the attempt has been abandoned for this year. Some details are given. Camp IV on the North Col was reached on May 26, but owing to bad conditions was abandoned five days later. It was reoccupied on June 5 and on the following day Camp $V$ at 25,300 ft. was established. Conditions were not promising although the weather was good at the time. There was an exceptionally early monsoon with heavy snowfalls. Avalanches were unusually numerous and several times endangered the expedition. On June 8, Messrs. Shipton and Smythe established Camp VI at 27,000 ft., where they were joined by Messrs. Tilman and Lloyd, but beyond $27,300 \mathrm{ft}$. the snow made progress impossible and the attempt was abandoned. Two of the porters are seriously ill, but the rest of the party is well.

\section{The First Radio Valve}

SIR Felix PoLe recently made a presentation to Mr. Charles Corbett, who has completed fifty years unbroken service with the Edison Swan Electrical Co., Ltd. Sir Felix pointed out that the company is the oldest electric lamp concern in Great Britain, and is the Company to whom Sir Ambrose Fleming was consultant when he produced the first radio valve. In 1878, Sir Joseph Swan exhibited at Newcastle-on. Tyne the first electric lamp, and in 1881 formed the Swan Electric Light Co., Ltd., to manufacture and market electric lamps. Two years later the names of Thomas Alva Edison and Joseph Swan were coupled by the amalgamation of their interests and patents in the formation of the Edison and Swan United Electric
Light Co., Ltd. The factory became established at Ponders End. In 1916, the Company's name was changed to the Edison Swan Electric Co., Ltd. About the time of the amalgamation, Edison noted the irregular blackening of the inside of the lamp bulb during life. Later, this 'Edison effect' was investigated in the laboratory by Sir Ambrose Fleming (then Prof. J. A. Fleming), and a number of special carbon filament lamps were made for him for experimental purposes. The result was, in 1904, the

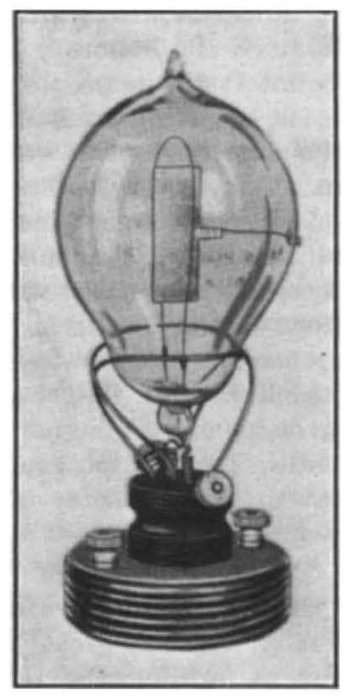

Fleming thermionic valve. Although this valve was no more than a simple carbon lamp of the period with a metal plate placed between the legs of a hairpin-shaped filament, it could detect wireless signals without the disadvantages common to the old coherers and other mechanical detectors. Much remained to be done before the valve could be brought to that stage of comparative efficiency which was reached with the advent of broadcasting, but something of the physics of the valve had been learned.

\section{University of London Observatory}

ON July 1, in spite of a severe thunderstorm during which the roof of Mr. Will Hay's house was set on fire by lightning, one hundred and sixty people attended the opening, by the Astronomer R syal, of the new building of the University of London $\mathrm{Ob}$ servatory at Mill Hill, in which the 24-in. Radeliffe photographic refractor from Oxford and a library have been installed. The Astronomer Royal was introduced to the guests (among whom were the Mayor and Mayoress of Hendon) in a short speech by Sir Frank Dyson, chairman of the University Observatory Committee of Management, and gave an account of some of the circumstances which led to the founding of the Observatory in 1929. This had been largely due, he said, to the enthusiasm of the late Prof. L. N. G. Filon, who was made honorary director, and to Mr. C. C. L. Gregory, who was given the title of Wilson Observer. Mention was made of the Wilson 24-in. reflecting telescope which was presented to the University by Mr. J. G. Wilson, and 